\title{
Nils Holtug
}

\section{Metode i politisk filosofi}

Metoden i moderne analytisk politisk filosofi kendetegnes ved følgende fire elementer; begrebsanalyse, konsistens/universaliserbarhed, rationaler og moralske intuitioner. Disse fire elementer karakteriseres og eksemplificeres og de indbyrdes relationer kortlægges. Der argumenteres desuden for, at de fire elementer udgør legitime metodiske krav, uanset hvilket mere specifikt ståsted vi har inden for en bred vifte af teorier om politiske normers epistemiske og ontologiske status.

Politisk filosofi - eller den form for politisk filosofi jeg vil beskæftige mig med her - er en normativ disciplin. Den er normativ i den forstand, at den søger at besvare spørgsmål om, hvilke principper et samfund skal være indrettet efter, for at det kan siges at være retfærdigt, hvad der gør en given politik rigtig eller forkert osv. Den behandler med andre ord spørgsmål om, hvordan et samfund (inklusive det internationale samfund) bør være indrettet. Især beskæftiger den sig med mulige begrundelser for forskellige samfundsindretninger, og hvad der gør disse begrundelser gode eller dårlige.

Inden for andre discipliner vækker det nogle gange undren, at politiske filosoffer søger at besvare denne slags normative spørgsmål. Det hænger sammen med, at der i den akademiske verden er en vis skepsis over for, om overvejelser over normative spørgsmål kan tillægges nogen form for erkendelsesmæssig værdi. I den forstand afspejler denne undren en skepsis over for muligheden af politisk filosofi, der i sin tid blev formuleret af de logiske positivister. Logiske positivister som fx. Alfred Ayer (1936) hævdede, at normative sætninger ikke kan være sande eller falske, da de slet ikke beskriver noget, men derimod udtrykker holdninger eller følelser. At tilslutte sig det repræsentative demokrati som styreform er dermed bare at tilkendegive en positiv holdning til det repræsentative demokrati snarere end at fremsætte en vurdering, der kan tilskrives en erkendelsesmæssig værdi.

Hos de logiske positivister var denne forståelse af normative sætningers (manglende) erkendelsesmæssige værdi et produkt af en generel semantisk teori, ifølge hvilken der kun er to slags sætninger, der er meningsfulde, nemlig analytiske og empirisk verificerbare. Analytiske sætninger (fx. " $2+2=4$ ") er sande eller falske alene i kraft af deres mening, hvorimod empirisk verificerbare sætninger (fx. "græsset er grønt") er sande eller falske, alt efter om de beskriver den empiriske verden korrekt. Og da normative sætninger ifølge positivisterne 
hverken er analytiske eller empirisk verificerbare, kan de ikke have sandhedsværdi.

Der er imidlertid ingen filosoffer, der længere tilslutter sig en sådan simpel semantisk teori. Det logisk positivistiske program brød sammen af en række grunde, herunder at det blev klart, at dette program ikke selv lever op til sine egne krav om videnskabelighed. For eksempel er sætningen "kun analytiske og empirisk verificerbare sætninger er meningsfulde" hverken analytisk eller empirisk verificerbar, og dermed er den, ifølge de logiske positivisters egne kriterier, ikke meningsfuld.

Selv længe efter den logiske positivismes sammenbrud var filosoffer imidlertid betænkelige ved at bedrive politisk filosofi, og det var først da John Rawls i 1971 udgav A Theory of Justice, at den politiske filosofi for alvor kom på dagsordenen igen. Rawls specificerede heri ganske kortfattet en metode, kendt som reflekteret ligevagt, men det har formentlig i langt højere grad været den konkrete måde, hvorpå han argumenterede for sin retfærdighedsteori, end teoretiske refleksioner over metoden, der i første omgang inspirerede kolleger til at følge trop og igen sparke liv i den politiske filosofi.

I det følgende vil jeg beskrive, hvad jeg anser som de vigtigste metodiske træk ved analytisk politisk filosofi, sådan som den er blevet bedrevet, siden Rawls udgav $A$ Theory of Justice. I virkeligheden mener jeg, at man langt hen ad vejen også finder disse træk i megen anden filosofi, og for den sags skyld også i en række discipliner uden for filosofien. Men her vil jeg fokusere specifikt på politisk filosofi. Efter at have beskrevet disse træk vil jeg argumentere for, at de udgør legitime metodiske krav inden for politisk filosofi, uanset hvilket mere specifikt ståsted vi har inden for en bred vifte af teorier om politiske normers epistemiske og ontologiske status.

\section{Begrebsanalyse}

En helt central del af den politiske (og anden) filosofi går ud på at analysere de begreber, vi bruger inden for disciplinen (Jackson, 1998). Inden for politisk filosofi vil det selvfølgelig langt hen ad vejen dreje sig om begreber, der udtrykker politiske vardier, fx. demokrati, ytringsfrihed, lighed og sammenhængskraft. Ved at klargøre begreberne kan vi dels få bedre styr på, hvad værdierne egentlig går ud på, dels få et bedre overblik over, hvilke implikationer de har.

Begrebsanalyser har ofte den karakter, at de specificerer, hvad de nødvendige og tilstrækkelige betingelser er for at bruge et givet begreb (korrekt). De vil derfor (ofte) have følgende form: 
hvor "x" er en variabel, "P" er det begreb, man forsøger at definere/karakterisere, og "___" er en pladsholder for definitionen/karakteristikken. For eksempel kunne følgende være et forsøg på en begrebsanalyse af "demokratisk samfund":

$\mathrm{x}$ er et demokratisk samfund, hvis og kun hvis de politiske ledere i $\mathrm{x}$ vælges af folket ix.

Typisk vil man i begrebsanalyser afprøve analysen ved at forsøge at finde modeksempler. Således synes ovenstående analyse af "demokrati” at være sårbar over for en indvending om, at den er forenelig med, at et lille flertal fratager resten af befolkningen hovedparten af deres borgerrettigheder. Dette eksempel kan således siges at udgøre et modeksempel til analysen, og i mange analyser af demokratibegrebet vil mindretalsbeskyttelse følgelig indgå som en central komponent.

Lad mig give et par eksempler fra aktuelle politisk filosofiske diskussioner, hvor det bliver klart, at det faktisk har stor betydning, præcis hvad begreberne indeholder. Ifølge Derek Parfit (1991) er der en række politiske filosoffer, der hævder at tilslutte sig egalitarisme, som i virkeligheden snarere tilslutter sig et andet fordelingspolitisk princip, nemlig prioritetsprincippet. Ifølge egalitarisme er det alt andet lige dårligt, hvis nogle er stillet værre end andre (uden selv at være skyld heri). ${ }^{1}$ Ifølge prioritetsprincippet er det alt andet lige bedre at gavne et individ, jo dårligere stillet han eller hun er (uden selv at være skyld heri). Sidstnævnte princip indebærer, at ulighed i sig selv ikke er noget, vi bør tage hensyn til. Derimod bør vi tage hensyn til ulighedens konsekvenser for de individer, den går ud over; de sultendes sult, de nødstedtes nød, de syges lidelser osv. (Raz, 1986: 240).

Det er vigtigt at sondre mellem disse to principper, blandt andet fordi de har forskellige implikationer. En central del af vores forstålse af lighedsidealet er, at et mere lige samfund alt andet lige er bedre end et mindre lige samfund. Det er med andre ord en nødvendig betingelse for, at et ideal kan være et lighedsideal, at det indebærer, at et mere lige samfund alt andet lige er bedre. Det indebærer ikke nødvendigvis, at et mere lige samfund er bedre alt taget $i$ betragtning, da vi jo kan have andre værdier også, der nogle gange kommer i konflikt med lighed (herunder hensynet til effektivitet og/eller frihed). Men for en egalitarist må et mere lige samfund nødvendigvis være bedre end et mindre lige samfund i én henseende, nemlig hvad angår lighed. Det følger af begrebsanalysen af lighed (Holtug, 2010a: Kap. 7).

Netop denne præcisering af lighedsidealet er vigtig, fordi den i moderne politisk filosofi har givet anledning til en indflydelsesrig indvending mod lig- 
hedsidealet. Dette ideal indebærer nemlig, at hvis man tilvejebringer lighed ved at trække alle ned på de dårligst stilledes niveau, så er det i én henseende en forbedring. Der vil så være fuldkommen lighed. Men hvordan kan der være tale om en forbedring i nogen henseende, når ingen - ikke engang de dårligst stillede - vinder noget herved?

Prioritetsprincippet, derimod, er ikke sårbart over for indvendingen. Princippet hævder nemlig ikke, at lighed er værdifuldt, og derfor indebærer det ikke, at det i nogen henseende er godt at stille alle lige på de dårligst stilledes niveau. Ved at skelne mellem de to principper, der hidtil ofte er blevet sammenblandet, var Parfit altså i stand til dels at forklare, at de bygger på forskellige værdier, dels at de har forskellige implikationer og derfor er sårbare over for forskellige indvendinger. (For yderligere diskussion af forskellen på egalitarisme og prioritetsprincippet og af den nævnte indvending mod førstnævnte, se Holtug, 2006, 2010a; Parfit, 1991; Temkin, 1993: kap. 8).

Det andet eksempel, jeg vil give, er relevant $i$ forbindelse med en række problemstillinger i politisk filosofi, herunder problemstillinger inden for den såkaldte populationsetik, der blandt andet omhandler spørgsmålet om, hvor mange mennesker, der bør eksistere i fremtiden (dvs. hvad der er en optimal befolkningsstørrelse). Dette spørgsmål er fx. relevant i forbindelse med beslutninger om global opvarmning og fattigdomsbekæmpelse i den tredje verden.

Overvej følgende eksempel, der ligeledes stammer fra Parfit (1984: kap. 19):

Figur 1: Parfits additionsparadoks

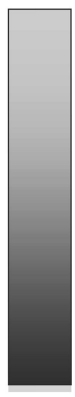

A

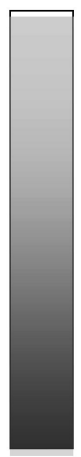

$\mathrm{A}^{+}$
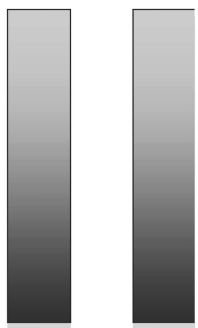

$\mathrm{B}$

$\mathrm{A}, \mathrm{A}^{+}$og $\mathrm{B}$ er udfald, hvor bredden på søjlerne angiver, hvor mange mennesker der er i en gruppe, og højden angiver, hvor meget velfærd (livskvalitet) de har. I $\mathrm{A}^{+}$består den første søjle af de samme mennesker, som findes i A, og den anden 
søjle af en ny gruppe mennesker, som er blevet skabt. I $\mathrm{A}^{+}$er den første gruppe således stillet lidt bedre end i A, og der er født en ny gruppe mennesker, der har dårligere liv end den første gruppe, men ikke desto mindre rimeligt gode liv. I B findes de to samme grupper som i $\mathrm{A}^{+}$, hvor den første gruppe er stillet lidt dårligere, og den anden gruppe væsentligt bedre end i $\mathrm{A}^{+}$.

Parfit argumenterer nu for, at $\mathrm{A}^{+}$er mindst lige så god som $\mathrm{A}$. $\mathrm{A}^{+}$er bedre for den første gruppe og tydeligvis ikke værre for den anden gruppe, da de har liv, der klart er værd at leve, og ikke ville have eksisteret, hvis A var det faktiske udfald. Ganske vist er der ulighed i $\mathrm{A}^{+}$, men vi kan antage, at de to grupper ikke har nogen kontakt med hinanden, og dermed at uligheden ikke ødelægger relationerne i mellem dem eller er udtryk for social uretfærdighed.

Ligeledes synes $\mathrm{B}$ at være mindst lige så god som $\mathrm{A}^{+}$. Den gevinst, som den anden gruppe får i B i forhold til $\mathrm{A}^{+}$, er nemlig større end den første gruppes tab, og gevinsten tilfalder desuden de dårligst stillede. Givet at $\mathrm{A}^{+}$er mindst lige så god som $\mathrm{A}, \mathrm{og} \mathrm{B}$ er mindst lige så god som $\mathrm{A}^{+}$, så følger det desuden, at B er mindst lige så god som A. Problemet er nu, at man på denne måde kan blive ved med at øge antallet af mennesker og samtidig sænke gennemsnitsvelfærden i skridt, der er parallelle til overgangen fra A til B, og at man dermed til sidst ender med den konklusion, at et udfald med en enorm population af mennesker, der alle har liv, der kun lige er værd at leve, er mindst lige så god som A (hvor vi kan forestille os, at A består af 10 milliarder meget lykkelige mennesker). Denne konklusion synes ikke meget bedre end den, Parfit (1984: 388) kalder den afskyelige konklusion, ifølge hvilken udfaldet med den enorme population er bedre end A.

Den afskyelige konklusion hedder selvfølgelig sådan, fordi den forekommer temmelig frastødende, og der er gjort forskellige forsøg på at undgå den, såvel som den lidt mere moderate konklusion, at udfaldet med den enorme population er mindst lige så godt som A. Et af disse forsøg omhandler slutningen fra, at $\mathrm{A}^{+}$er mindst lige så god som $\mathrm{A}, \mathrm{og} \mathrm{B}$ mindst lige så god som $\mathrm{A}^{+}$til, at $\mathrm{B}$ er mindst lige så god som A. Denne slutning forudsætter, at relationen "er mindst lige så god som" er en såkaldt transitiv relation. At en relation er transitiv betyder, at hvis x står i relationen til y, og y står i relationen til z, så følger det, at x står i relationen til z. Således er fx. identitet en transitiv relation. Hvis x=y og $\mathrm{y}=\mathrm{z}$, så følger det, at $\mathrm{x}=\mathrm{z}$. Umiddelbart synes "mindst lige så god som” også at have denne egenskab; hvis x er mindst lige så god som y, og y er mindst lige så god som $\mathrm{z}$, så må $\mathrm{x}$ være mindst lige så god som $\mathrm{z}$.

Det er dog ikke alle, der accepterer, at "mindst lige så god som" er en transitiv relation (Rachels, 1998; Temkin, 1987), og pointen er nu, at hvis vi benægter, at den er transitiv, så kan vi samtidig afvise ovenstående argument for 
den afskyelige konklusion. Dette og andre eksempler har rejst en diskussion af, hvorvidt relationen "mindst lige så god som" er transitiv - en diskussion, der fordrer en begrebsanalyse. Hvor nogle teoretikere således har forsøgt at give modeksempler til, at relationen er transitiv (inklusive ovenstående eksempel fra populationsetikken), har andre argumenteret for, at disse reelt ikke er modeksempler og for, at relationen synes nært beslægtet med (andre) komparativer, der tydeligvis er transitive (Broome, 2004: 50-63; se også Holtug, 2007: 52-56). (For eksempel er den komparative relation "er højere end" tydeligvis transitiv; hvis Mads er højere end Mette, og Mette er højere end Mikkel, så følger det, at Mads er højere end Mikkel). Pointen her er dog ikke, at "er bedre end" faktisk er en transitiv relation, men at en stillingtagen hertil kræver en begrebsanalyse.

\section{Konsistens}

Ligesom inden for andre discipliner er konsistens (modsigelsesfrihed) et metodekrav inden for politisk filosofi. Det hænger naturligvis sammen med, at selvmodsigelser - fx. "samfundet bør indrettes som et repræsentativt demokrati, og samfundet bør ikke indrettes som et repræsentativt demokrati" - slet og ret er indholdsløse, idet de ingenting kommunikerer. Inden for moral- og politisk filosofi benyttes desuden et mere vidtgående konsistenskrav, nemlig kravet om universaliserbarhed. Især den engelske moralfilosof Richard Hare har bidraget til formuleringen af dette krav, som der dog også kan findes versioner af hos Kant (1965) og i den gyldne regel. Ifølge Hare er det et logisk træk ved moralske (og politiske) vurderinger, at de kan gives en universel formulering, der følgelig ikke henviser til specifikke personer, tider eller situationer (Hare, 1963: 30). Det indebærer fx., at hvis en racist hævder, at en bestemt race ikke har krav på grundlæggende frihedsrettigheder, så må han være villig til at støtte denne vurdering selv i den hypotetiske situation, at han selv tilhører den pågældende race. Hare mener på den baggrund, at en del moralske og politiske vurderinger kan afvises, da deres fortalere reelt ikke lever op til universaliserbarhedstesen.

Hare begrunder universaliserbarhedstesen i en begrebsanalyse, eller mere specifikt i en analyse af moralske udtryks semantik. Han mener sågar, at han kan udlede et bestemt moralsk princip, nemlig totalutilitarisme, fra denne semantik (Hare, 1981). Hvor moralfilosoffer generelt har accepteret Hares ide om, at moralske vurderinger er universaliserbare, har de dog generelt ikke fundet belæg for hans tese om, at der kan udledes et bestemt moralsk princip fra de moralske udtryks semantik (Seanor og Fotion, 1988).

Selv hvis Hare tager fejl $\mathrm{i}$, at der kan udledes et bestemt moralsk princip fra moralske udtryks semantik, betyder det dog langt fra, at universaliserbar- 
hedstesen ingen funktion har i politisk filosofi. Faktisk kan en lang række af de argumenter, der fremføres inden for feltet, siges at forudsætte netop konsistenskravet og/eller universaliserbarhedstesen. Når fx. Amartya Sen (1997: 16-18) indvender mod utilitarisme, at den indebærer, at vi nogle gange på urimelig vis skal ofre dårligt stillede individer for at stille mere privilegerede mennesker (endnu) bedre, så forudsætter han konsistenskravet. Sens pointe er, at nogle mennesker er dårligere til at omsætte ressourcer til velfærd end andre, fx. fordi de er syge, og af den grund har sværere ved at omsætte ressourcerne til valgmuligheder (der er fx. en række aktiviteter, en person, der er permanent sengeliggende, vil have svært ved at udføre). Derfor vil de blive nedprioriteret af et princip, der indebærer, at ressourcerne skal tilføres de mennesker, der får mest velfærd ud af dem. Dermed peger Sen på en bestemt implikation af utilitarismen og påpeger, at den strider mod (er logisk uforenelig med) en plausibel moralsk intuition om, at det (i hvert fald i nogle situationer) er problematisk at nedprioritere de dårligt stillede, selv hvis det maksimerer summen af velfærd.

Bemærk dog, at kravet om konsistens/universaliserbarhed ikke af sig selv fortæller os, hvilke af to modstridende holdninger vi bør acceptere. Når Sen fx. påpeger, at utilitarismen strider mod et vidtgående hensyn til de dårligt stillede, så følger det jo kun, at vi er nødt til at forkaste ét af disse modstridende hensyn. Sen mener så, at det er utilitarismen, der bør forkastes, men det følger ikke i sig selv af modstriden, men af, at han intuitivt finder hensynet til de dårligst stillede vigtigst. Jeg udfolder denne metodiske ide om, at politisk filosofi også hviler på moralske intuitioner nærmere senere i artiklen, men foreløbig er pointen bare, at kravet om konsistens/universaliserbarhed tvinger os til at vælge mellem uforenelige synspunkter.

På den baggrund kan det måske se ud til, at kravet om konsistens/universaliserbarhed reelt ikke hjælper os særlig meget, når vi skal vælge mellem forskellige politiske synspunkter og teorier. Af forskellige grunde er det dog en forhastet konklusion. For det første bidrager kravet til at indsnævre antallet af sæt af synspunkter, vi har at vælge imellem, til kun at omfatte konsistente sæt. For det andet kan man, som Hare, argumentere for, at universaliserbarhedstesen i praksis udelukker mange synspunkter for langt de fleste mennesker. Blandt andet mener Hare som nævnt, at det er de færreste racister, der reelt er villige til at universalisere deres racisme. Og for det tredje tvinger kravet os til at tænke over, om de synspunkter, vi overvejer, er forenelige med andre holdninger, vi har, hvilket nogle gange kan afsløre uerkendte sammenhænge mellem holdninger. For eksempel var der, da de første forsøg med genterapi på mennesker blev udført, mange, der var betænkelige herved, da de mente, at forskerne "legede Gud”, når de ændrede på menneskers genetiske sammensætning. Det blev 
heroverfor påpeget, at organtransplantationer jo også indebærer ændringer i menneskers genetiske sammensætning, og at denne begrundelse (for modstanden mod genterapi) derfor har videre implikationer, end dens fortalere måske umiddelbart er opmærksomme på og parate til at acceptere.

\section{Rationaler}

En yderligere central metodisk komponent i den politiske filosofi er forsøget på at give rationaler, dvs. mere grundlæggende teoretiske begrundelser, for politiske principper. Et eksempel herpå er Rawls' begrundelse af sin retfærdighedsteori i $A$ Theory of Justice. En af de begrundelser, Rawls her giver for sine retfærdighedsprincipper, er, at de ville blive valgt af frie og lige individer, der søger at blive enige om et sæt af principper for, hvordan samfundet bør indrettes. Rawls sikrer her parternes lighed ved, at de i den såkaldte oprindelige position (valgsituationen) fratages en række informationer, de kunne bruge til at favorisere sig selv på bekostning af andre i valget af principper, herunder viden om deres klassetilhørsforhold, køn, intelligens, talenter mv. (Rawls, 1971: 12). Rawls hævder så, at det i den oprindelige position er rationelt for parterne at vælge et specifikt sæt af principper, som blandt andet inkluderer et princip, der er nært beslægtet med prioritetsprincippet, nemlig det såkaldte differensprincip, ifølge hvilket gruppen af dårligst stillede bør stilles bedst muligt (Rawls, 1971: 302303). Da ingen nemlig ved, hvilken position de selv indtager i samfundet, vil de søge at gardere sig ved at sikre, at den værst tænkelige situation - at tilhøre gruppen af de dårligst stillede - bliver så god som muligt.

Thomas Nagel har desuden givet et andet rationale for et princip, der minder om differensprincippet, som bygger på en ide om enstemmighed. Individers interesser vil nogle gange være i konflikt med hinanden, og vi kan derfor ikke altid træffe valg, der er helt acceptable for alle. Men vi kan gøre det næstbedste, nemlig træffe det valg, der er mindst uacceptabelt for det individ, for hvem det er mest uacceptabelt (Nagel, 1979: 123). På den måde sikrer vi mest mulig enstemmighed, forstået på den måde, at den største legitime klage, et individ kan have over fordelingen, er så lille så muligt. Og det udfald, der sikrer det, er et, hvor det dårligst stillede individ er stillet bedst muligt.

Hvor Rawls således giver et rationale for differensprincippet, der tager udgangspunkt i en mere fundamental ide om mennesker som frie og lige individer samt i en teori om rationelle valg under usikkerhed (den såkaldte maximinstrategi), giver Nagel et rationale, der tager udgangspunkt i ideen om, at den valgte fordeling skal sikre mest mulig enstemmighed. Hvorvidt disse to rationaler udgør plausible begrundelser kan naturligvis diskuteres (for kritik af henholdsvis Rawls' og Nagels begrundelse, se Hare, 1989; McKerlie, 1994), 
men i denne sammenhæng er pointen den mere beskedne, at appellen til rationaler er en udbredt måde at forsøge at begrunde principper på i politisk filosofi.

Ideen med at begrunde principper i rationaler er, at man derved opnår en stærkere begrundelse, end hvis man bare henviste til princippernes eventuelle intuitive plausibilitet. Man undgår desuden det, som Shelly Kagan (1989: 14) omtaler som "hængende distinktioner" (eng. dangling distinctions), dvs. distinktioner, hvis normative relevans ikke er begrundet.

Rationalets bidrag til begrundelsen af princippet kan forklares på to måder. Nogle teoretikere vil henvise til, at de værdier, et plausibelt rationale hviler på, må have en højere grad af troværdighed, end principperne selv har, eller at de ligefrem er selvindlysende, for at rationalet begrunder principperne. Andre vil derimod sige, at de værdier, rationalet hviler på, ikke nødvendigvis er mere troværdige, men at jo flere og stærkere begrundelsesrelationer, der findes inden for et givet sæt af værdier, jo mere velbegrundet er dette sæt. Disse to forskellige måder at forstå rationalers begrundelsesmæssige betydning på, der knytter sig til henholdsvis fundamentalistiske og kohærentistiske teorier om begrundelse, vender jeg tilbage til senere.

\section{Intuitioner}

Det sidste træk, jeg vil pege på, hvad angår metoden i politisk filosofi, er også det mest kontroversielle. Det drejer sig om brugen af moralske (eller politiske) intuitioner, hvilket vil sige moralske (politiske) overbevisninger, man finder intuitivt plausible, fx. en intuition om, at tortur er forkert, eller at staten ikke bør fremme kristendom på bekostning af andre livsanskuelser. Der er vel at mærke to forskellige måder, hvorpå intuitioner bruges i politisk filosofi. Dels bruges intuitioner inden for begrebsanalyse til at kortlægge, hvad vi dybest set mener med givne begreber, herunder moralske og politiske begreber (Jackson, 1998: 31-37). Ved eksempelvis at se på, om vi mener, statslige forbud mod rygning på offentlige steder er forenelige med borgernes autonomi, bliver vi klarere på, hvad vi mener med "autonomi", og bliver muligvis også klar over, at begrebet bruges forskelligt af forskellige aktører, hvilket i sig selv kan bidrage til at klargøre en række debatter.

Det er dog den anden brug af intuitioner, der er den mest kontroversielle. Her bruges intuitioner ikke bare til at kortlægge vores moralske og politiske begreber, men derimod til at begrunde moralske og politiske principper. Det taler med andre ord til fordel for et givet princip, at det stemmer overens med vores intuitioner, hvorimod det tenderer til at underminere princippet, hvis vores intuitioner strider imod det. Det er fx. således, Sen bruger sin intuition om, at det i hvert fald i nogle situationer er uretfærdigt, hvis de dårligt stilledes 
interesser tilsidesættes, også selvom man herved kan maksimere den samlede sum af velfærd i samfundet. Han mener med andre ord, at det taler imod utilitarismen, at den har en sådan kontraintuitiv implikation.

Det er dog ikke nødvendigvis alle moralske intuitioner, der er velegnede til at begrunde principper. For eksempel understreger Rawls (1971: 48), at det kun er velovervejede moralske intuitioner, der bør indgå i begrundelsen. Heri ligger, at de er udformet under omstændigheder, hvor man ikke er indlysende partisk, vred, bange, uligevægtig eller lignende.

Nogle teoretikere finder ikke desto mindre brugen af intuitioner til at begrunde politiske principper suspekt. De mener, at intuitionerne ikke kan tjene til at begrunde principper, medmindre vi har uafhængige grunde til at tro, at disse intuitioner er sande eller i hvert fald velbegrundede (Brandt, 1979: 20; Hare, 1981: 12; Singer, 1974; se også Lippert-Rasmussens artikel i dette nummer). Andre teoretikere tvivler derimod på, at vi kan begrunde politiske principper eller for den sags skyld andre teorier uden i sidste ende at henvise til intuitioner:

Nogle filosoffer mener, at det, at noget er intuitivt plausibelt, udgør et meget spinkelt grundlag for at tro på det. Selv mener jeg, at det udgør stærk evidens for hvad som helst. På en måde ved jeg ikke, hvilken form for mere konklusiv evidens man i sidste ende kan have for noget som helst (Kripke, 1980: 42).

I næste afsnit vil jeg argumentere for, at brugen af moralske intuitioner faktisk kan retfærdiggøres ud fra en bred vifte af positioner inden for metaetik, dvs. teorier om etikkens og politikkens grundlag. Men foreløbig vil jeg fokusere på, hvordan intuitioner indgår som metodisk komponent i politisk filosofi.

Ofte bruges intuitioner som en del af en øvelse, der går ud på at isolere en bestemt faktor i en problemstilling for at identificere, hvilken normativ relevans faktoren har. Tænk fx. på ovenstående indvending mod egalitarisme, ifølge hvilken det er uplausibelt at hævde, at det i bare én henseende er godt at tilvejebringe lighed, hvis det sker ved, at alle stilles på de dårligst stilledes niveau. For at tage stilling til, om dette er en god indvending, er vi nødt til at antage, at alt andet er lige. Det vil sige, at vi sammenligner to udfald, hvor det ene er ulige, og det andet lige (på de dårligst stilledes niveau), hvor disse to udfald ikke adskiller sig fra hinanden i andre henseender. Det er fordi vi gerne vil fokusere på, om lighed virkelig kan være værdifuldt i bare én henseende, når den indebærer, at nogle stilles dårligere, mens ingen stilles bedre. Hvis nu fx. udfaldene i øvrigt adskilte sig på den måde, at individerne var mere frie i det lige udfald, så kunne vi jo ikke konkludere, at lighed kan være værdifuldt, 
også når den ikke gavner nogen, selv hvis vi mente, at det lige udfald er bedre i én henseende. Det kunne jo være, fordi dette udfald indeholder mere frihed, at vi syntes sådan. Og det siger jo ikke i sig selv noget om vores intuitioner om lighed.

På nogle punkter minder denne isolationsmetode selvfølgelig om, hvordan man inden for andre discipliner undersøger en given problemstilling. Når man fx. inden for lægevidenskab ønsker at teste effekten af et givet præparat og gør det ved at give præparatet til en gruppe forsøgspersoner, hvorimod præparatet ikke gives til kontrolgruppen, så nytter det jo ikke noget, hvis man samtidig giver forsøgspersonerne noget andet, som kontrolgruppen ikke får. Så ved man jo ikke, om det er præparatet eller det andet, forsøgspersonerne får, der har en eventuel effekt på forsøgspersonerne. Parallelt hermed er man nødt til at isolere en bestemt faktor, fx. en forskel i lighed, når man tager stilling til, om man mener, at denne faktor er normativt betydningsfuld.

Man kan selvfølgelig opponere mod, at de værdier, man dermed undersøger, fjernes fra den sociale kontekst, de fungerer i (Goodin, 1982: 8-9). Hvis fx. individer generelt har større (eller mindre) frihed, hvis de er stillet nogenlunde lige godt, så kan det synes problematisk at abstrahere fra denne sammenhæng, når man undersøger værdierne. Alternativt kan det indvendes, at det kun er samfund, der indeholder bestemte former for fællesskab, der overhovedet er i stand til at realisere lighed, og at det er problematisk at se bort fra disse lighedens forudsætninger i diskussioner af lighed i politisk filosofi. Sidstnævnte indvending trækker desuden på en generel kommunitaristisk kritik af megen liberal tænkning (Taylor, 1992).

Jeg mener dog, at disse indvendinger hviler på en misforståelse. At isolere lighed, når man tager stilling til dens værdi, indebærer jo ikke, at man benægter, at frihed (eller alt muligt andet) har værdi. Samme metode er man så nødt til at bruge, når man undersøger frihedens værdi. Men for at undgå fx. at tilskrive lighed en værdi, der egentlig er en værdi ved frihed, eller omvendt, er man nødt til at isolere dem som en del af metoden.

Der er ikke noget i vejen for, at de to værdier samtidig kan have indflydelse på hinanden. Det kan fx. være, at lighed kun har værdi, når den realiseres inden for rammerne af et frit samfund eller omvendt. Men pointen er, at også den ide kan vi bedst teste vores intuitioner om, hvis vi på behørig vis isolerer den faktor, vi ønsker at fokusere på. Vi kan så sammenligne situationer, hvor vi varierer graden af lighed $i$ et frit samfund med situationer, hvor vi varierer graden af lighed i et ufrit samfund. Hvis variationer i lighed kun ændrer på værdien af udfaldet i det frie samfund, taler det for, at værdien af lighed forudsætter frihed. 
Hvad angår tesen om, at lighed kun kan realiseres i et samfund, der er bundet sammen af en bestemt form for fællesskab, fx. sammenhængskraft eller en bestemt social ethos, er den ligeledes helt forenelig med isolationsmetoden. ${ }^{2}$ Denne tese angår nemlig ikke direkte værdien af lighed, men derimod forudsætningerne for, at værdien kan realiseres i et givet samfund. For så vidt lighed er værdifuldt, bør vi selvfølgelig søge at tilvejebringe forudsætningerne for, at værdien kan trives, alt andet lige. Men pointen er, at disse forudsætninger har vi kun grund til at tilvejebringe, for så vidt lighed faktisk er værdifuldt (eller bidrager til noget andet, som er værdifuldt), og vi har derfor brug for en metode, der gør os i stand til at tage stilling til det.

Ligesom man skal passe på ikke at sammenblande en given faktors værdi med vigtigheden af dens kausale forudsætninger, skal man desuden passe på med ikke at sammenblande dens værdi med vigtigheden af dens kausale konsekvenser. Nogle indvender således mod egalitarisme, at lige samfund tenderer til at være mindre effektive, og at ligheden således går ud over størrelsen på den samlede kage, vi har at fordele. Men selv hvis det er rigtigt, ${ }^{3}$ så indebærer det jo bare ikke, at lighed ikke er værdifuldt, men muligvis at lighed skal afvejes over for andre værdier, fx. effektivitet. Det er således ikke en indvending mod isolationsmetoden, at de værdier, vi bruger den til at undersøge, har yderligere konsekvenser, for så vidt de implementeres. Det er bare en påmindelse om, at når vi vurderer politikker, så skal vi forsøge at tage de samlede konsekvenser i betragtning med fokus på hele viften af værdier, de fremmer eller hæmmer.

Et yderligere spørgsmål angår, hvilke typer eksempler, det kan være relevant at teste politiske principper i forhold til. Sens eksempel med patienter, der pga. deres sygdom har sværere ved at omsætte deres ressourcer til velfærd end andre, er et hverdagseksempel, og det er blandt andet af den grund relativt ukontroversielt som en form for intuitiv test på utilitarismen. Eksemplet, hvor vi sammenligner et ulige udfald med et lige udfald, hvor alle er stillet på de dårligst stilledes niveau, kan derimod synes mere hypotetisk, for hvornår står vi lige og skal vælge mellem sådan to udfald? Svaret er imidlertid, at det gør vi ganske ofte - vi kunne fx. vælge at fratage de bedre stillede deres ressourcer (og destruere ressourcerne), indtil de når de dårligst stilledes niveau. Når vi ikke seriøst overvejer denne mulighed, hænger det snarere sammen med, at vi finder den moralsk uansvarlig.

Det er imidlertid ikke alle de eksempler, der overvejes i politisk filosofi, der indeholder en sådan grad af realisme. For eksempel henviser Larry Temkin (2003: 69) til en case, hvor en mineralrig asteroide bevæger sig gennem universet, og man med sit rumskib kan skubbe den sikkert ned på en planet, hvor mineralerne kan bruges til at forbedre indbyggernes liv. Temkin spørger nu, 
om det er vigtigere at føre mineralerne ned til planeten, hvis borgerne på denne planet er stillet dårligere end borgerne på alle andre planeter, end hvis de er stillet bedre end alle andre? (Bemærk at borgerne på denne planet er stillet lige godt i de to scenarier; det er kun niveauet på de andre planeter, der varierer.) Tanken er så, at hvis vi mener, at det er vigtigere at hjælpe dem, hvis alle andre er stillet bedre, så taler det for egalitarisme snarere end for prioritetsprincippet. Ifølge prioritetsprincippet afhænger værdien nemlig kun af, hvor godt eller dårligt beboerne på planeten selv er stillet, hvorimod egalitarisme indebærer, at den afhænger af, hvor godt eller dårligt de er stillet $i$ forhold til andre (om mineralerne bringer mere eller mindre lighed $\mathrm{i}$ universet).

Temkin kalder selv eksemplet "far-fetched", og spørgsmålet er så, om det gør det mindre anvendeligt til at teste vores intuitioner om principperne, at det ikke er realistisk? Nogle teoretikere forholder sig skeptisk over for værdien af sådanne eksempler. For eksempel skriver Hare, hvad angår intuitive modeksempler til utilitarisme: ${ }^{4}$

Det mest almindelige trick blandt utilitarismens modstandere er at tage udgangspunkt i eksempler på den slags tænkning [tænkning der angår rigtighedskriterier], typisk anvendt på fantastiske cases, og sammenligne dem med, hvad almindelige mennesker ville synes (Hare, 1990: 31).

Her er det dog afgørende, hvad man mener med, at eksemplerne ikke er realistiske. Denne ide kunne udlægges som, at vi kun bør benytte os af intuitioner om faktiske eksempler - dvs. eksempler, der foreligger i den virkelige verden - og ikke af hypotetiske eksempler. Problemet er dog her, at vi ikke ved, hvilke eksempler der er faktiske, da vi ikke ved, hvad fremtiden bringer, fx. med hensyn til muligheden for at høste mineraler fra asteroider.

Et andet bud kunne være, at vi kun bør benytte os af historiske og nutidige eksempler, dvs. eksempler, der nu foreligger eller har foreligget i den virkelige verden. Heller ikke dette bud forekommer dog plausibelt. Et vigtigt element i politisk filosofi synes netop at være, at den skal sætte os i stand til at håndtere nye situationer, teknologier mv., og i lyset heraf forekommer det problematisk, hvis vi ikke kan teste vores principper i forhold til de udfordringer, fremtiden kan bringe. Det var fx. nye teknologier, der gjorde Holocaust mulig, og det synes i høj grad relevant at teste vores principper i forhold til sådanne scenarier, herunder katastrofale scenarier, som vi kan tænkes at blive konfronteret med.

Et tredje bud kunne være, at kun eksempler, der involverer sandsynlige begivenheder, bør inddrages i diskussionen af politiske principper. Heller ikke dette bud forekommer dog plausibelt. Massive radioaktive udslip fra atom- 
kraftværket i Barsebäck er (forhåbentlig) overordentlig usandsynlige, men vores principper bør ikke desto mindre kunne hjælpe os til at tage stilling til teknologier som $\mathrm{fx}$. atomkraft.

I stedet kunne man hævde, at kun eksempler, der er fysisk, eller metafysisk eller logisk mulige, er relevante i forhold til testningen af vores principper. ${ }^{5} \mathrm{Her}$ forekommer det mig uplausibelt at sige, at kun eksempler, der er fysisk mulige, er anvendelige. Tænk fx. på Harry Frankfurts argument for, at vi godt kan have moralsk ansvar, selvom vores handlinger er determinerede (et argument der blandt andet er relevant for, hvilke uligheder der ifølge egalitarismen bør udlignes, og hvilke man med rimelighed kan holde folk ansvarlige for selv). Frankfurt (1988) overvejer et eksempel, hvor videnskabsmænd har kontrol over en persons hjerne på en sådan måde, at medmindre personen selv beslutter at udføre en given handling, så manipulerer de hendes hjerne sådan, at hun alligevel udfører handlingen. Frankfurts pointe er, at hvis personen af sig selv beslutter at udføre handlingen, så bliver hun ikke mindre ansvarlig for handlingen af, at hun ikke kunne undgå at udføre den (hvis hun ikke selv havde besluttet det, var hendes hjerne blevet manipuleret til at træffe beslutningen).

$\mathrm{Nu}$ er det jo svært at vide, om den form for manipulation af hjernen, der i givet fald skulle til, er forenelig med naturlovene, men det er også svært at se, at det er relevant, om den er det. Det afgørende i eksemplet er, om vores begreb om moralsk ansvar er foreneligt med, at kvinden er ansvarlig for handlingen, og her synes det irrelevant, om den omtalte form for manipulation er fysisk mulig. Det er selvfølgelig afgørende, at tankeeksperimentet er logisk muligt (dvs. ikke selvmodsigende) og formentlig også, at det er metafysisk muligt, men det er der ingen grund til at betvivle. ${ }^{6}$

Robert Goodin indvender dog, at vi ikke kan have tillid til vores intuitioner om situationer, der afviger for meget fra dem, hvorunder vi i sin tid har formet intuitionerne. I den forbindelse henviser Goodin (1982: 11) til et eksempel, hvor to ældre, døende mænd bebor en (ellers) øde ø, og vi skal tage stilling til, om deres pligt til at holde deres løfter forsvinder, fordi et eventuelt løftebrud ikke vil underminere den generelle tillid til løfteinstitutionen (da de begge er ved at dø og ikke har indflydelse på andre). Goodin påpeger her, at hvis vi mener, at de bør holde deres løfter, så kan det være, fordi vi er under indflydelse af, at vores intuitioner er formet i et samfund, hvor løftebrud generelt tenderer til at underminere løfteinstitutionen, hvilket ikke er relevant i denne situation.

Det afgørende synes imidlertid at være, om vi kan fastholde synspunktet om, at det er forkert at lyve, selv i situationer, hvor det ikke har negative konsekvenser (såsom at underminere tillid). Hermed bliver vi klogere på, hvad vi mener grunden er til, at det (normalt) er forkert at lyve. Og det er svært at se, 
at der er bedre måder at blive klogere på det på end ved skiftevis at forestille os, at de faktorer, der kunne tænkes at gøre det forkert at lyve, ikke er til stede. Det er jo netop det, eksemplet med den øde ø lægger op til. Hvis vi omvendt kun forestiller os situationer, hvor alle løgnens sædvanlige konsekvenser er til stede, kan det være svært for os at skelne mellem de forskellige faktorers værdimæssige bidrag, herunder når vi skal tage stilling til, om løgnen er forkert i sig selv eller pga. dens negative konsekvenser. Desuden er der noget, der tyder på, at det faktisk kan lade sig gøre at se bort fra, at løgn generelt underminerer tillid og har andre negative konsekvenser, i og med at nogle faktisk vurderer, at det ikke er forkert at lyve i eksemplet.

\section{Metaetiske positioner}

I dette sidste afsnit vil jeg kort diskutere, hvorledes de anførte metodeelementer er forenelige med en bred vifte af metaetiske positioner. Særligt vil jeg fokusere på brugen af intuitioner, da dette som sagt er det mest kontroversielle element i metodologien.?

Ofte forbindes påstanden om, at moralske intuitioner har epistemisk vægt med kohærentistiske teorier om begrundelse og i særdeleshed med Rawls' teori om reflekteret ligevægt (Rawls, 1971: 17-22, 46-53; se også Brink, 1989: Kap. 5; Daniels, 1979; Tersman, 1993). Ifølge teorien om reflekteret ligevægt er et politisk princip retfærdiggjort, for så vidt at det kohærerer med vores velovervejede moralske intuitioner og (muligvis) med vores baggrundsteorier ( $\mathrm{fx}$. psykologiske, sociologiske, økonomiske og metafysiske teorier). Her gælder desuden de sædvanlige kriterier for kohærens, herunder konsistens, forklaringskraft og simplicitet.

Mere generelt kan den angivne metodologi snildt forenes med en kohærentistisk teori om begrundelse. Alle de epistemiske desiderata, jeg har angivet, bidrager således til kohærensen af et sæt af formodninger. En politisk teori bliver mere kohærent i takt med, at den bliver mere konsistent, kan begrundes ud fra et rationale og har intuitivt plausible implikationer. Ligeledes bidrager begrundelsesrelationer mellem baggrundsteorier og politiske principper til at øge kohærensen. Et eksempel herpå kunne være en metafysisk begrundelse for fri vilje, der understøtter et politisk princip om, at individer nogle gange bør holdes ansvarlige for deres egne valg og således ikke bør kompenseres af staten, hvis de er dårligere stillet end andre af grunde, som de selv er ansvarlige for (se fx. diskussionen i Holtug, 2010b).

Teorien om reflekteret ligevægt findes i både individualistiske og kollektivistiske versioner. Forskellen er, at i individualistiske versioner er det den begrundende persons egne intuitioner, der tages udgangspunkt $i$, mens det i kol- 
lektivistiske versioner er "vores" intuitioner, dvs. intuitioner, der er udbredte. I praksis vil der dog ofte ikke være den store forskel, da også individualistiske teoretikere generelt forsøger at appellere til intuitioner, der har en vis udbredelse, da de jo ellers ikke kan gøre sig det store håb om at overbevise andre. Principielt er der dog en forskel, og det vil fx. være mere oplagt at inddrage egentlige empiriske undersøgelser af samfundsborgeres værdier på baggrund af kollektivistiske versioner.

Kohærensteorier om begrundelse er forenelige med en række forskellige teorier om moralens ontologi (dvs. læren om, på hvilke måder moralske egenskaber/kendsgerninger er til). De er således forenelige med både reduktionistiske (naturalistiske) teorier, ifølge hvilke moralske egenskaber kan reduceres til naturlige (fx. psykologiske) egenskaber. Men de er også forenelige med nonreduktionistiske (intuitionistiske) teorier, ifølge hvilke moralske egenskaber er særlige egenskaber ved virkeligheden, der ikke kan reduceres til andre typer egenskaber. Endelig er de forenelige med anti-realistiske, konstruktivistiske doktriner, ifølge hvilke moralske egenskaber ikke findes uafhængigt af menneskers holdninger, men hvor kohærens ikke bare er kriteriet for begrundelse, men også for (moralsk og politisk) sandhed.

Det er ikke kun kohærensteorier om begrundelse, der betjener sig af moralske intuitioner. Det gør fundamentalistiske begrundelsesteorier også. Ifølge sådanne teorier er politiske principper begrundede i den udstrækning, de hviler på selvindlysende eller i hvert fald oplagte moralske sandheder (Audi, 1996). I det mindste er det nærliggende at forstå tanken om, at disse sandheder er selvindlysende/oplagte, som en påstand om, at vi har særligt stærke intuitioner om deres rigtighed (som $\mathrm{fx}$. intuitionen om, at det er moralsk forkert at torturere uskyldige mennesker for sjov).

Fundamentalister med hensyn til begrundelse lægger ligeledes stor vægt på konsistens og typisk også på betydningen af rationaler for politiske principper. Ideen er nemlig, at man kan udlede en række moralske eller politiske domme fra de selvindlysende sandheder, teorien betjener sig af, og hermed kommer disse sandheder til at tjene som en form for rationaler for andre domme.

Der er selvfølgelig også teoretikere, der mener, at førnævnte begrundelsesidealer er for ambitiøse i det moralske og politiske domæne. Det kan fx. være, fordi de mener, at moralske og politiske vurderinger dybest set bare er udtryk for smag og behag, og at sådanne vurderinger derfor ikke kan være sande eller falske eller på anden vis særligt kvalificerede. Dette synspunkt, non-kognitivisme, er dog langt mindre udbredt blandt metaetikere, end man måske umiddelbart skulle tro. Og synspunktet er da også radikalt. Hvis ikke det kvalificeres yderligere, indebærer det fx, at det blot er et spørgsmål om smag og behag, om 
det er forkert at torturere uskyldige mennesker for sjov, og om apartheiden i Sydafrika var en retfærdig måde at indrette samfundet på. Endvidere vil selv non-kognitivister typisk mene, at det er et logisk krav, at vores sæt af moralske og politiske intuitioner skal være konsistente, og på den måde fastholde i hvert fald en del af den metodologi, jeg har beskrevet i denne artikel.

\section{Noter}

1. Eller rettere, dette er en bestemt (udbredt) form for egalitarisme, som Parfit benævner "telisk" (eller teleologisk) egalitarisme (Parfit, 1991: 3-4). Når jeg i det følgende taler om egalitarisme, er det denne teliske form, jeg har i tankerne. Jeg forudsætter også, medmindre andet er anført, at de mennesker, der er stillet ulige, ikke selv er skyld i uligheden.

2. Hvad angår den sociale sammenhængskraft, er der dog noget, der tyder på, at den kausale sammenhæng er omvendt. Socioøkonomisk lighed i samfundet tenderer til at skabe højere grad af tillid mellem borgerne (Uslaner, 2002: Kap. 6 og 8).

3. Hvilket dog ikke er et spørgsmål, jeg tager stilling til her. I en vismandsrapport fra 2001 konkluderes det, at der ikke er noget entydigt empirisk svar på sammenhængen mellem ulighed og vækst (Det Økonomiske Råd, 2001: 119).

4. Det skal dog siges, at Hare ikke kun er skeptisk over for anvendelsen af fantastiske (dvs. urealistiske) cases, men helt generelt over for anvendelsen af intuitioner til at teste principper.

5. For en diskussion af, hvilke mulige verdner vores filosofiske teorier skal kunne redegøre for, se Kirkham (1997: Kap. 1). Kirkham fokuserer på teorier om sandhed, men hans diskussion har også relevans for andre typer teorier, herunder politiske.

6. I Holtug (2010a) argumenterer jeg for, at også hvad angår betydningen af teorier om personlig identitet for teorier om retfærdighed, er det relevant at teste principper på baggrund af eksempler, der er metafysisk (men ikke nødvendigvis fysisk) mulige.

7. Dette afsnit bygger på Holtug (2010a: 7-14).

\section{Litteratur}

Audi, Robert (1996). "Intuitionism, Pluralism, and the Foundations of Ethics", pp. 101-136 i Walter Sinnott-Armstrong og Mark Timmons (red.), Moral Knowledge, New York: Oxford University Press.

Ayer, Alfred J. (1936). Language, Truth and Logic, Harmondsworth: Penguin Books (oprindelig trykt af Victor Gollancz).

Brandt, Richard (1979). A Theory of the Good and the Right, Oxford: Clarendon Press. 
Brink, David O. (1989). Moral Realism and the Foundations of Ethics, Cambridge: Cambridge University Press.

Broome, John (2004). Weighing Lives, Oxford: Oxford University Press.

Daniels, Norman (1979). "Wide Reflective Equilibrium and Theory Acceptance in Ethics”, Journal of Philosophy, 76. årg., nr. 4, pp. 256-282.

Frankfurt, Harry G. (1988). "Alternate Responsibilities and Moral Responsibility", pp. 1-10 i Harry G. Frankfurt, The Importance of What We Care About, Cambridge: Cambridge University Press.

Goodin, Robert (1982). Political Theory and Public Policy, Chicago: University of Chicago Press.

Hare, Richard M. (1963). Freedom and Reason, Oxford: Clarendon Press.

Hare, Richard M. (1981). Moral Thinking, Oxford: Clarendon Press.

Hare, Richard M. (1989). "Rawls's Theory of Justice", pp. 145-174 i Richard M. Hare, Essays in Ethical Theory, Oxford: Clarendon Press.

Hare, Richard M. (1990). "Ethical Theory and Utilitarianism", pp. 23-38 i Amartya Sen og Bernard Williams (red.), Utilitarianism and Beyond, Cambridge: Cambridge University Press.

Holtug, Nils (2006). "Prioritarianism", pp. 125-56 i Nils Holtug og Kasper LippertRasmussen (red.), Egalitarianism. New Essays on the Nature and Value of Equality, Oxford: Clarendon Press.

Holtug, Nils (2007). "A Note on Conditional Egalitarianism", Economics and Philosophy, 23. årg., nr. 1, pp. 45-63.

Holtug, Nils (2010a). Persons, Interests, and Justice, Oxford: Oxford University Press.

Holtug, Nils (2010b). "Lige muligheder som ideal i politisk filosofi", pp. 21-44 i Nils Holtug og Kasper Lippert-Rasmussen (red.), Lige muligheder for alle. Social arv, kultur og retfardighed, København: Nyt fra samfundsvidenskaberne.

Jackson, Frank (1998). From Metaphysics to Ethics. A Defence of Conceptual Analysis, Oxford: Clarendon Press.

Kagan, Shelly (1989). The Limits of Morality, Oxford: Clarendon Press.

Kant, Immanuel (1965). Grundlegung zur Metaphysik der Sitten, Hamburg: Felix Meiner Verlag.

Kirkham, Richard L. (1997). Theories of Truth, Cambridge, MA: The MIT Press.

Kripke, Saul (1980). Naming and Necessity, Oxford: Basil Blackwell.

McKerlie, Dennis (1994). "Equality and Priority", Utilitas, 6. årg., nr. 1, pp. 25-42.

Nagel, Thomas (1979). "Equality", pp. 106-127 i Thomas Nagel, Mortal Questions, Cambridge: Cambridge University Press.

Parfit, Derek (1984). Reasons and Persons, Oxford: Clarendon Press. 
Parfit, Derek (1991). Equality or Priority, University of Kansas: The Lindley Lecture (genoptrykt i Matthew Clayton og Andrew Williams (red.), The Ideal of Equality, Basingstoke: Macmillan Press, Inc. 2000).

Rachels, Stuart (1998). "Counterexamples to the Transitivity of Better Than", Australasian Journal of Philosophy, 76. årg., nr. 1, pp. 71-83.

Rawls, John (1971). A Theory of Justice, Oxford: Oxford University Press.

Raz, Joseph (1986). The Morality of Freedom, Oxford: Clarendon Press.

Seanor, Douglas og Nick Fotion (red.) (1988). Hare and Critics, Oxford: Oxford University Press.

Sen, Amartya (1997). On Economic Inequality, 2nd. ed., Oxford: Clarendon Press.

Singer, Peter (1974). "Sidgwick and Reflective Equilibrium", The Monist, 58. årg., pp. 420-448.

Taylor, Charles (1992). "Atomism", pp. 29-50 i Schlomo Avineri og Avner de-Shalit (red.), Communitarianism and Individualism, Oxford: Oxford University Press.

Temkin, Larry (1987). "Intransitivity and the Mere Addition Paradox", Philosophy and Public Affairs, 16. årg., nr. 2, pp. 138-187.

Temkin, Larry (1993). Inequality, Oxford: Oxford University Press.

Temkin, Larry (2003). "Equality, Priority, or What?", Economics and Philosophy, 19. årg., pp. 61-87.

Tersman, Folke (1993). Reflective Equilibrium. An Essay in Moral Epistemology, Stockholm: Almqvist \& Wiksell International.

Uslaner, Eric (2002). The Moral Foundations of Trust, Cambridge: Cambridge University Press.

Økonomiske Råd, Det (2001). Dansk økonomi, Det Økonomiske Råd. 